\title{
Mothers' Knowledge and Practices for their Children with Sickle Cell Anemia At New Valley Governorate Hospitals
}

\author{
Shereen M. Abed El Fatah, Amal A. Mobarak \& Zienab M. Mohi Edien. \\ Head Nurse in El Kharga general hospital at New Valley governorate Egypt. \\ Lecturer of pediatric nursing Faculty of Nursing, Assuit University Egypt. \\ Professor of Pediatrics Faculty of Medicine, Assuit University Egypt.
}

\begin{abstract}
Sickle cell disease (SCD) is a genetic blood disorder associated with multiple health complications including anemia and recurrent pain episodes. Objectives: This study aimed to assess the mothers' knowledge and practices for children with SCA at New Valley governorate hospitals. Design: A descriptive research design was utilized in this study. Subjects and method: This study included 45 mothers of children who were diagnosed with SCA. Setting This study was conducted in the inpatient pediatric unit and pediatric clinics at New Valley governorate hospitals. Tool: A structured interview sheet was utilized to collect the necessary data. Results: It was found that more than one third (40\%) of mothers had satisfactory knowledge. Slightly more than one third of mothers, (35.6\%) had poor knowledge about SCA. It was found that half of mother's (51.1\%) had satisfactory level of practice, while $48.9 \%$ had unsatisfactory level of practice regarding SCA. conclusion the low level of maternal education was a significant risk factor for the poor knowledge and poor practices of the mothers regarding management of SCA. Recommendations: Effective genetic counseling, neonatal screening test should be applied at the New valley governorate hospitals for early detection of SCA, and health education program sessions for mothers of children with SCA.
\end{abstract}

Key words: Sickle Cell Anemia, Sickle Cell Trait, Genetic Blood Disorders.

\section{Introduction}

Sickle cell disease (SCD) refers to a spectrum of autosomal recessive genetic disorders of hemoglobin, an oxygen-carrying red blood cell protein. These chronic hematological disorders include sickle cell anemia (HbSS) and other genetic presentations of the disease. The severest type of SCD is the sickle cell anemia, in which two copies of the hemoglobin variant HbSS are present. Sickle cell anemia is also the most common type of SCD, with $65 \%$ of children having the HbSS genotype (Wang, 2007).

Sickle cell disease is considered the most prevalent genetic hematological disorder and affects approximately 72,000 people in the United States, primarily of African, Mediterranean, Caribbean, South and Central American, Arab, and East Indian descent (Ashley-Koch et al., 2000). More specifically, SCD occurs in approximately 1 of every 350-700 African American births and in 1 of every 1,000 to 1,400 Hispanic American births in the United States (Wang, 2007). The highest frequency of sickle cell disease is found in tropical regions, particularly sub-Saharan Africa, India and the Middle-East (Weatherall \& Clegg, 2001). Sicklecell disease (SCD) is not frequent in Egypt except in the Oases where the carrier rate varies from 9 to $22 \%$ (El-Beshlawy\&Youssry,2009).

Normal hemoglobin, hemoglobin A ( $\mathrm{HbA})$, is the main oxygen-carrying protein found in red blood cells. Hemoglobin is made of two alpha-globin and two beta-globin chains. In SCD, at least one sickled beta-globin gene is inherited. When both sickled beta globin genes are inherited, HbSS is the resulting genotype (Lemanek \& Ranalli, 2009).

The oxygen and nutrient deprivation, along with the accumulation of toxic waste products, contributes to the acute and chronic clinical symptoms seen in individuals with SCD. The mean life expectancy of individuals with the HbSS genotype is 42 years for males and 48 for females (Platt et al., 1994).

Infants with SCD generally do not exhibit clinically observable evidence of disease until six months of age because healthy fetal hemoglobin remains in the body until about three months of age. Between three and six months, adult hemoglobin replaces fetal hemoglobin. Because adult hemoglobin is impaired in individuals with SCD, the negative effects of the disease become observable around six months of age, when the levels of abnormal hemoglobin rise in infants (Smith \& Baker, 2011).

One of the hallmark clinical features of SCD is vasooccclusive crisis, which is experienced as episodes of pain. Pain episodes are considered acute when they result from blocked blood flow and chronic when they occured due to damage from repeated pain episodes and tissue ischemia (Franck et al., 2002). 
Pain episodes can vary in location, intensity, and quality among individuals with SCD. Pain associated with vaso-occlusive crises is often described as uncomfortable, achy and steady. This pain is observed most frequently in the extremities, the hips, or the abdomen. Pain crises are most often managed in the home with analgesic medication (Dampier et al., 2002). The worsening of pain can also be prevented by applying heat or touch and consuming fluids. When pain becomes severe enough, however, hospital admission may be required. In fact, one-half to two-thirds of hospital admissions in children with SCD are related to pain crises (Gil et al., 2000).

Physical exertion, extreme temperatures, and stress were noted as aggravating factors for sickle cell crisis. A typical medication regimen for an individual with frequent pain episodes includes hydroxyurea therapy, analgesics, and possible red blood cell transfusion therapy (Taylor et al., 2010). Analgesic therapy, both opioids and non-opioids, is commonly used to treat acute pain in the home setting. Nonopioids most frequently include nonsteroidal anti-inflammatory drugs (Niscola et al., 2009). Exchange transfusions and hydroxyurea therapy are also used as preventive strategies to reduce levels of $\mathrm{Hgb} \mathrm{S}$ and have been helpful in decreasing pain, but these do not completely prevent crises. Some barriers to providing effective pain relief in the home were identified as limited knowledge of coping strategies and inadequate knowledge about the use of analgesics to control pain (Dampier et al., 2002).

Nurse plays a vital role in the education of the child and family regarding non pharmacologic techniques for pain management, as well as in the implementation of such techniques while the child is hospitalized. Nursing care of the child with SCD and fever includes prompt IV antibiotic administration, monitoring of vital signs for signs and symptoms of sepsis, antipyretic administration, and education of the family regarding SCD and fever. Patient and family education regarding acute febrile illness should include a basic review of splenic dysfunction, discussion regarding when to call the doctor or clinic, the importance of prompt medical attention with fever, thermometer use and verification that a working thermometer is in the home, and appropriate medication administration teaching (Jakubik \& Thompson, 2000).

Many pain crises can be managed at home. child will need to increase fluid intake and should use the pain pills prescribed by their doctor. If care of the pain at home is not effective, medical care will be right away. In addition to drinking lots of water and taking pain pills, there are many other ways to help child fight the pain of sickle cell disease. As with other kinds of pain, it's best to use many different approaches at once to get the best pain relief. Biofeedback, cognitive strategies, selfhypnosisand progressive relaxation all show great promise as useful treatments to add in to the usual sickle cell pain treatment (Kyla and Brendan, 2009).

\section{Aim of the Study}

This study aimed to assess the mothers' knowledge and practices for their children with sickle cell anemia at New Valley governorate hospitals.

\section{Research questions}

What is the mothers' knowledge about care of their children with sickle cell anemia?

What is the mothers' practices regarding care of their children with sickle cell anemia?

\section{Subjects \& method}

Research design

Descriptive research design was utilized to meet the aim of this study.

\section{Setting}

This study was conducted in the inpatient pediatric unit and pediatric clinics of El Kharga general hospital, El Dakhla general hospital, and El Farafra hospital).

\section{Subjects}

A purposive sample of children with sickle cell anemia (45) and their mothers as following: 39 mothers from El Kharga city, 2 mothers from El Dakhla city, and 4 mothers from El Farafra city.

\section{Inclusion criteria}

Mothers of children with sickle cell anemia from 1 month to 17 years old and agree to participate in the study.

\section{Tools of data collection}

A structured questionnaire sheet to collect the required data for this study. It consisted of three parts:

Part (I)

Characteristics of the studied mothers as: the mother's name, age, educational level, occupation, residence, consanguineous relationships, number of children, family number and family history for sickle cell anemia.

(II) Characteristics of the studied children as: the child's age, sex, birth order, and the level of education.

\section{Part two}

Questions to assess the mothers' knowledge about sickle cell anemia such as definition, causes, signs and symptoms, diagnosis, precipitating factors of sickle cell crisis, preventive measures to prevent 
vaso-occlusive crisis and the complications of sickle cell anemia.

\section{Part three}

Questions to assess the mothers' reported practices related to care of their children with sickle cell anemia such as places and persons referred to during crisis, follow up, nutrition, and medications.

\section{Scoring system}

A structured questionnaire sheet for mothers' knowledge: it consisted of 26 questions. The score that was given for subjects responses was:

(Two) grades $\rightarrow$ for complete correct, (one) grade $\rightarrow$ for incomplete correct and (zero) grade $\rightarrow$ for incorrect or not responding.

The total scoring of mothers' knowledge was done as follows:

Poor $<50 \%$

Satisfactory $50-70 \%$

Good $\geq 70$

II: Questionnaire sheet for mothers' reported practices: it consisted of 24 questions.

The score that was given for subjects response was Two $\rightarrow$ for completely done, one $\rightarrow$ for done incompletely

and zero $\rightarrow$ for not done.

The total scoring for mothers' reported practices was done as follows

Satisfactory $\geq 60 \%$

Unsatisfactory $<60 \%$

Method of data collection

An official letter from the faculty of nursing, Assiut University, was prepared and delivered to the director of New Valley governorate hospitals (El Kharga general hospital, El Dakhla general hospital, and El Farafra hospital) to carry out the study

\section{Ethical Considerations:}

- Research proposal was approved from ethical committee in the Faculty of Nursing.

- There is no risk for study subject during application of the research.

- Oral consent was obtained from mothers who are willing to participate in the study, after explaining the nature and purpose of the study.

- Confidentiality and anonymity was assured.

- Study subject have the right to refuse to participate and or withdraw from the study without any rational any time.

- Confidentiality of data was asserted. Every mother was reassured that information obtained would be confidential and used only for the purpose of the study.

- The study tools were developed by researcher based on the literature review and it was tested for its content validity and reliability by exposing to five experts in the pediatric field.
- A pilot study was carried out on $5 \%$ of mothers and their children with sickle cell anemia at New Valley governorate hospitals to test the clarity of the tools for applicability and estimate time needed for each.

- Data were collected by the researcher through interviewing the mothers in groups (3mothers) to deliver the developed questionnaire sheet to them to collect the needed data. The time needed to fulfill each sheet ranged from 20-30 minutes to fill sheet depending upon the response of the participant mother. The actual work started by meeting the mothers throughout the morning time, every day except Fridays and a home visit was done to the mothers who are not hospitalized at New Valley hospitals. The phone was used to fill the sheet for cases of El Farafra general hospital due to long distances. Data were collected during the period from beginning of February 2012 to the end of May 2012.

\section{Statistical analysis}

Data entry and data analysis were done by using SPSS program (statistical package for social science) version 16. Data were presented as number, percentage, mean, and standard deviation. Chi-square and Fisher exact test were used to compare qualitative data. Pearson correlation was used to measure correlation score of knowledge and practice. P-value considered statistically significant when $\mathrm{p}<0.05$. 


\section{Results}

Table (1):Characteristics of the studied mothers.

\begin{tabular}{|c|c|c|}
\hline Items & $N=45$ & $\%$ \\
\hline \multicolumn{3}{|l|}{ Mother age } \\
\hline$<35$ years & 14 & 31.1 \\
\hline $35-<40$ years & 14 & 31.1 \\
\hline$\geq 40$ years & 17 & 37.8 \\
\hline Mean \pm SD (Range) & \multicolumn{2}{|c|}{$37.82 \pm 7.70(23-55)$} \\
\hline \multicolumn{3}{|l|}{ Level of education: } \\
\hline Less than secondary & 7 & 15,6 \\
\hline Secondary/ diploma & 29 & 64.4 \\
\hline University & 9 & 20.0 \\
\hline \multicolumn{3}{|l|}{ Occupation } \\
\hline Working & 27 & 60.0 \\
\hline Housewife & 18 & 40.0 \\
\hline \multicolumn{3}{|l|}{ Residence } \\
\hline Urban & 42 & 93.3 \\
\hline Rural & 3 & 6.7 \\
\hline \multicolumn{3}{|l|}{ Number of children in family } \\
\hline $1-3$ & 28 & 62.2 \\
\hline$>3$ & 17 & 37.8 \\
\hline \multicolumn{3}{|l|}{ Consanguinity } \\
\hline Yes & 13 & 28.9 \\
\hline No & 32 & 71.1 \\
\hline \multicolumn{3}{|c|}{ Family history for sickle cell anemia } \\
\hline Yes & 20 & 44.4 \\
\hline No & 25 & 55.6 \\
\hline
\end{tabular}

Table (2):Characteristics of the studied children.

\begin{tabular}{|l|c|c|}
\hline \multicolumn{1}{|c|}{ Items } & N=45 & \% \\
\hline Child's age & \multicolumn{2}{|c|}{} \\
\hline$<6$ years & 9 & 20.0 \\
\hline $6-<12$ years & 25 & 55.6 \\
\hline$\geq 12$ years & 11 & 24.4 \\
\hline Mean \pm SD & \multicolumn{2}{|c|}{$9.42 \pm 1.19(2 \mathrm{y}, 3 \mathrm{~m}-17 \mathrm{y})$} \\
\hline Child's sex & 29 & 64.4 \\
\hline Male & 16 & 35.6 \\
\hline Female & \multicolumn{2}{|c|}{} \\
\hline Birth order & 16 & 35.6 \\
\hline $1^{\text {st }}$ & 7 & 26.6 \\
\hline $2^{\text {nd }}$ & 12 & 26.7 \\
\hline $3^{\text {rd }}$ & 10 & 2.2 \\
\hline $4^{\text {th }}$ or more & \multicolumn{2}{|c|}{} \\
\hline Level of education & 9 & 68.8 \\
\hline Kindergarten & 31 & 11.1 \\
\hline Primary education & 5 & \multicolumn{2}{|c|}{} \\
\hline Secondary / diploma & \multicolumn{2}{|c|}{} \\
\hline
\end{tabular}


Table (3):Frequency distribution of the mothers' knowledge about sickle cell anemia.

\begin{tabular}{|c|c|c|}
\hline Mothers' knowledge & $\mathrm{N}=45$ & $\%$ \\
\hline \multicolumn{3}{|l|}{ Definition of SCA } \\
\hline Complete correct & 1 & 2.2 \\
\hline Incomplete correct & 27 & 60.0 \\
\hline Incorrect & 17 & 37.8 \\
\hline \multicolumn{3}{|l|}{ Inherited disease } \\
\hline Yes & 30 & 66.7 \\
\hline No & 15 & 33.3 \\
\hline \multicolumn{3}{|l|}{ Signs and symptoms of SCA:\# } \\
\hline Mild jaundice & 44 & 97.8 \\
\hline Urine color is red or brown & 40 & 88.9 \\
\hline Fever & 37 & 82.2 \\
\hline Joints pain & 34 & 75.6 \\
\hline Severe abdominal pain & 30 & 66.7 \\
\hline Painful swelling of hands and feet & 23 & 51.1 \\
\hline Headache & 11 & 24.4 \\
\hline Recurrent bacterial infections & 6 & 13.3 \\
\hline Growth retardation & 3 & 6.7 \\
\hline Dyspnea on exertion & 3 & 6.7 \\
\hline \multicolumn{3}{|l|}{ Complications of SCA } \\
\hline Know & 0 & 0.0 \\
\hline Didn't know & 45 & 100.0 \\
\hline \multicolumn{3}{|c|}{ Consanguinity marriage is a cause for acquiring $\mathrm{SCA}$} \\
\hline Yes & 23 & 51.1 \\
\hline No & 22 & 48.9 \\
\hline \multicolumn{3}{|l|}{ Prevention of sickle cell anemia:\# } \\
\hline Premarital counseling & 9 & 20.0 \\
\hline Avoid consanguinity marriage & 3 & 6.7 \\
\hline Both & 6 & 13.3 \\
\hline Didn't know & 27 & 60.0 \\
\hline
\end{tabular}

\#Number is not mutually exclusive

Table (4): Frequency distribution of the mother's knowledge about precipitating factors and prevention of sickle cell crisis.

\begin{tabular}{|l|c|c|}
\hline \multicolumn{1}{|c|}{ Mothers' knowledge } & N=45 \\
\hline The precipitating factors of sickle cell crisis:\# & \multicolumn{2}{|c|}{} \\
\hline Infections (especially respiratory tract infection) & 31 & 68.9 \\
\hline Exposure to heat or cold & 24 & 53.3 \\
\hline Excessive physical exertion & 23 & 51.1 \\
\hline Traveling to high altitude & 5 & 11.1 \\
\hline Dehydration due to vomiting, or diarrhea & 2 & 2.4 \\
\hline Didn't know & 10 & 2.2 \\
\hline Prevention of sickle cell crisis:\# & & 62.2 \\
\hline Early treatment during infection & 28 & 42.2 \\
\hline Avoid exposure to heat or cold & 19 & 40.0 \\
\hline Use of prophylactic drugs & 18 & 33.3 \\
\hline Early diagnosis and follow up & 15 & 31.1 \\
\hline Avoid extensive sport and excessive physical exertion & 14 & 24.4 \\
\hline Increase fluid intake & 11 & 8.9 \\
\hline Avoid traveling to high altitude & 4 & 20.0 \\
\hline Didn't know & 9 & \\
\hline
\end{tabular}

\# Number is not mutually exclusive 
Table (5):Frequency distribution of mother's reported practices related to child nutrition.

\begin{tabular}{|l|c|c|}
\hline \multicolumn{1}{|c|}{ Items } & N=45 \\
\hline Nutrition during sickle cell crisis:\# & \multicolumn{2}{|c|}{} \\
\hline A usual nutrition & 39 & 86.7 \\
\hline Avoid the iron-rich foods & 23 & 51.1 \\
\hline Increase vegetables & 9 & 20.0 \\
\hline The iron-rich foods are forbidden & \multicolumn{2}{|c|}{} \\
\hline Yes & 35 & 77.8 \\
\hline No & 10 & 22.2 \\
\hline Types of the iron-rich foods:\# & \multicolumn{2}{|c|}{} \\
\hline Eggplant & 36 & 80.0 \\
\hline Liver & 28 & 62.2 \\
\hline Molasses & 22 & 48.9 \\
\hline Apple & 21 & 46.7 \\
\hline Others & 23 & 51.1 \\
\hline Increasing fluid intake during sickle cell crisis & \multicolumn{2}{|l|}{} \\
\hline Yes & 31 & 68.9 \\
\hline No & 14 & 31.1 \\
\hline
\end{tabular}

\# Number is not mutually exclusive

Table (6): Relation between mothers' characteristics and their total level of knowledge.

\begin{tabular}{|c|c|c|c|c|c|c|c|c|}
\hline \multirow{3}{*}{ Mothers' characteristics } & \multicolumn{6}{|c|}{ Mothers' knowledge } & \multirow{3}{*}{$\mathbf{X}^{2}$} & \multirow{3}{*}{ P-value } \\
\hline & \multicolumn{2}{|c|}{$\begin{array}{c}\text { Poor } \\
(n=16)\end{array}$} & \multicolumn{2}{|c|}{$\begin{array}{c}\text { Satisfactory } \\
(n=18)\end{array}$} & \multicolumn{2}{|c|}{$\begin{array}{c}\text { Good } \\
(n=11)\end{array}$} & & \\
\hline & No. & $\%$ & No. & $\%$ & No. & $\%$ & & \\
\hline \multicolumn{7}{|l|}{ Mother's age } & \multirow{4}{*}{4.94} & \multirow{4}{*}{0.293} \\
\hline$<35$ years & 4 & 28.6 & 7 & 50.0 & 3 & 21.4 & & \\
\hline $35-<40$ years & 4 & 28.6 & 4 & 28.6 & 6 & 42.9 & & \\
\hline$\geq 40$ years & 8 & 47.1 & 7 & 41.2 & 2 & 11.8 & & \\
\hline Level of education & & & & & & & \multirow{4}{*}{32.23} & \multirow{4}{*}{$0.000 *$} \\
\hline Less than secondary & 6 & 85.7 & 1 & 14.3 & 0 & 0.0 & & \\
\hline Secondary/ diploma & 10 & 34.5 & 16 & 55.2 & 3 & 10.3 & & \\
\hline University & 0 & 0.0 & 1 & 11.1 & 8 & 88.9 & & \\
\hline \multicolumn{7}{|l|}{ Occupation } & \multirow{3}{*}{10.22} & \multirow{3}{*}{$0.006^{*}$} \\
\hline Working & 5 & 18.5 & 12 & 44.4 & 10 & 37.0 & & \\
\hline Housewife & 11 & 61.1 & 6 & 33.3 & 1 & 5.6 & & \\
\hline \multicolumn{7}{|c|}{ Number of children in family } & \multirow{3}{*}{5.21} & \multirow{3}{*}{0.074} \\
\hline $1-3$ & 8 & 28.6 & 10 & 35.7 & 10 & 35.7 & & \\
\hline$>3$ & 8 & 47.1 & 8 & 47.1 & 1 & 5.9 & & \\
\hline \multicolumn{7}{|c|}{ Family history for sickle cell anemia } & \multirow{3}{*}{0.683} & \multirow{3}{*}{0.711} \\
\hline Yes & 7 & 35.0 & 7 & 35.0 & 6 & 30.0 & & \\
\hline No & 9 & 36.0 & 11 & 44.0 & 5 & 20.0 & & \\
\hline
\end{tabular}


Table (7): Relation between mothers' characteristics and their total percentage frequency score of practice.

\begin{tabular}{|c|c|c|c|c|c|c|}
\hline \multirow{3}{*}{ Mothers' characteristics } & \multicolumn{4}{|c|}{ Mothers' Practices } & \multirow{3}{*}{$\mathbf{X}^{2}$} & \multirow{3}{*}{ P-value } \\
\hline & \multicolumn{2}{|c|}{$\begin{array}{c}\text { Unsatisfactory } \\
(n=22)\end{array}$} & \multicolumn{2}{|c|}{ Satisfactory $(n=23)$} & & \\
\hline & No. & $\%$ & No. & $\%$ & & \\
\hline \multicolumn{5}{|l|}{ Mother age } & \multirow{4}{*}{5.15} & \multirow{4}{*}{0.076} \\
\hline$<35$ years & 5 & 35.7 & 9 & 64.3 & & \\
\hline $35-<40$ years & 5 & 35.7 & 9 & 64.3 & & \\
\hline$\geq 40$ years & 12 & 70.6 & 5 & 29.4 & & \\
\hline \multicolumn{5}{|l|}{ Level of education } & \multirow{4}{*}{6.36} & \multirow{4}{*}{$0.041 *$} \\
\hline Less than secondary & 6 & 85.7 & 1 & 14.3 & & \\
\hline Secondary/diploma & 14 & 48.3 & 15 & 51.7 & & \\
\hline University & 2 & 22.2 & 7 & 77.8 & & \\
\hline \multicolumn{5}{|l|}{ Occupation } & \multirow{3}{*}{1.79} & \multirow{3}{*}{0.181} \\
\hline Working & 11 & 40.7 & 16 & 59.3 & & \\
\hline Housewife & 11 & 61.1 & 7 & 38.9 & & \\
\hline \multicolumn{5}{|l|}{ Number of children in family } & \multirow{3}{*}{5.15} & \multirow{3}{*}{$0.023^{*}$} \\
\hline $1-3$ & 10 & 35.7 & 18 & 64.3 & & \\
\hline$>3$ & 12 & 70.6 & 5 & 29.4 & & \\
\hline \multicolumn{5}{|c|}{ Family history for sickle cell anemia } & \multirow{3}{*}{0.53 .8} & \multirow{3}{*}{0.463} \\
\hline Yes & 11 & 55.0 & 9 & 45.0 & & \\
\hline No & 11 & 44.0 & 14 & 56.0 & & \\
\hline
\end{tabular}

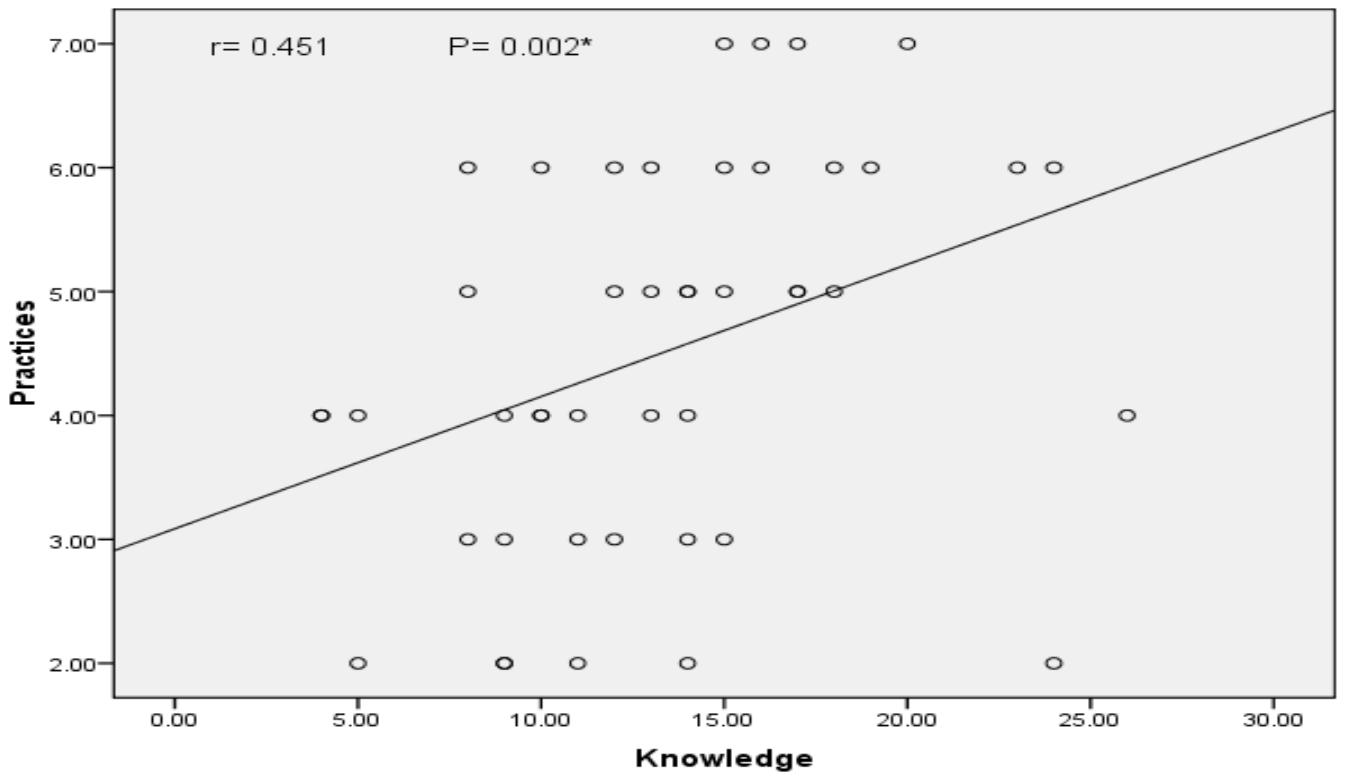

Fig. (1): Correlation between score of knowledge and score of reported practices of mothers.

Table (1): shows the characteristics of the studied mothers. It was found that the age of $37.8 \%$ of the mothers was ranged from 40 years or more, while $31.1 \%$ of them were less than 35 years, this table revealed that the mean age of the studied mothers was $37.82 \pm 7.70$. Regarding mothers' level of education, it was observed that nearly two thirds of mothers $(64.4 \%)$ were graduated from the secondary schools, while one quarter of them were highly educated and only $4.4 \%$ of them received primary education. Employee mothers constituted two thirds $(60 \%)$ of the study subjects, while less than half of them (40\%) were housewives.

Regarding the mothers' residence, the majority of mothers (93.3\%) were living in the urban areas, while only $6.7 \%$ were in the rural areas. More than two 
thirds of the mothers $(62.2 \%)$ had children number between 1-3 children $(62.2 \%)$, while less than half of the sample $(37.8 \%)$ had 4 to 7 children. Near threequarters of the motherss had not a consanguinity $(71.1 \%)$ while nearly one third of them $(28.9 \%)$ had a consanguinity. Concerning the family history of the disease among the studied mothers, the results revealed that $44,4 \%$ of them had a positive history.

Table (2): Illustrates characteristics of the studied children. It was observed that more than half of children $(55.6 \%)$ aged from 6 years $\leq 12$ years, and nearly one quarter of them $(24.4 \%)$ of them were 12 years or more while $20 \%$ were less than 6 years with a mean age of $9.42 \pm 1.19(2 \mathrm{y}, 3 \mathrm{~m}-17 \mathrm{y})$ years. Concerning the sex of the studied children, it was found that more than two thirds of children $(64.4 \%)$ were males while less than half of the sample $(35.6 \%)$ were females.

Concerning the children' birth order; it was found that one third of children $(35.6 \%)$ was the $1^{\text {st }}$ born child group, while less than one quarter of them $(15.6 \%)$ was among the $2^{\text {nd }}$ born child group. More than half of the children are at the primary education $(68.8 \%)$, while less than one quarter of them $(11.1 \%)$ are at secondary and diploma schools.

Table (3): Presents the frequency distribution of mothers general knowledge about sickle cell anemia. Regarding the definition of sickle cell anemia, it was observed that less than two thirds of mothers $(60 \%)$ gave incomplete correct definition of sickle cell anemia, while less than half of mothers $(37.8 \%)$ gave incorrect definition and only small percent $2.2 \%$ gave complete correct definition.

Regarding inheritance of sickle cell disease, it was found that two thirds of mothers $(66.7 \%)$ knew that sickle cell anemia is an inherited disease, while less than half of them $(33.3 \%)$ didn't know.

Concerning the manifestation of sickle cell anemia mentioned by the mothers, it was observed that the vast majority of manifestations known by mothers was mild jaundice (97.8\%), followed by change in urine color $(88.9 \%)$, fever $(82.2 \%)$, joint pain $(75.6 \%)$, severe abdominal pain $(66.7 \%)$, painful swelling of hands and feet $(51.1 \%)$, headache $(24.4 \%)$, and recurrent bacterial infections (13.3\%). However, small percentage knew that growth retardation, dyspnea and exertion $(6.7 \%)$ one sickle cell manifestations. All of mothers did not know the complications of sickle cell anemia (100\%). About half of the sample (51\%) believed that the consanguinity marriage is a cause for acquiring sickle cell anemia.

It was reported that more than half of mothers did not know the prevention of sickle cell anemia (60\%), while less than one quarter $(20 \%)$ of their answers were prevention through premarital counseling , while a small portion through avoiding consanguinity marriage $(6.7 \%)$, and both through premarital counseling, and avoiding consanguinity marriage $(13.3 \%)$.

Table (4): Presents the frequency distribution of mother's knowledge about precipitating factors and prevention of sickle cell crisis. Concerning the precipitating factors of sickle cell crisis, it was found that nearly two thirds of mothers $(68.9 \%)$ knew that infection was a risk factor. Regarding the exposure to heat and excessive physical exertion, more than half of the studied mothers knew that $(53.3 \%, 51.1 \%$ respectively). Less than one quarter of mother's knowledge $(11.1 \%, 4.4 \%$ respectively) knew that traveling to high altitude and dehydration due vomiting and diarrhea were risk factors, while $(22.2 \%)$ of mothers did not know about precipitating factors of sickle cell crisis.

Regarding mother's knowledge about prevention of sickle cell crisis, our results revealed that more than half of mothers $(62.2 \%)$ knew about early treatment during infection. As regards avoidance exposure to heat $(42.2 \%)$, and avoidance traveling to high altitude $(8.9 \%)$, while less than one quarter of mothers $(20 \%)$ did not know the prevention of sickle cell crisis.

Table (5): Shows the frequency distribution of the mothers' reported practices related to child nutrition. It was noticed that the majority of mothers $(86.7 \%)$ were giving a usual nutrition and more than half $(51.1 \%)$ of them were avoiding the iron-rich food, while $20.0 \%$ of them were increasing vegetables in their children's diet. It was noticed that more than three quarters of mothers $(77.8 \%)$ knew that the iron rich-food are forbidden for their children, while $22.2 \%$ of them did not know.

Regarding frequencies of mother's knowledge about the types of iron-rich food, were $(80 \%, 62.2 \%$, $48.9 \%, 46.7 \%, 51.1 \%$ respectively) for each of eggplant, liver, molasses, apple, and others not mentioned. It was found that the majority of mothers $(68.9 \%)$ were increasing fluid intake during the crisis while $31.1 \%$ were not.

As regards the increasing fluid intake during sickle cell crisis, it was found that more than two thirds of mother's practice ( $68.9 \%$ ) was to increase fluid intake during sickle cell crisis, while less than one third of mother's practice $(31.1 \%)$ was not increasing fluid intake during sickle cell crisis.

Table (6): Presents relationship between mothers' characteristics and their total level of knowledge.

The mothers' age didn't have any significant effect on the total level of mothers' knowledge (pvalue $=0.293$ ). Regarding the maternal educational level, those who had secondary/diploma level of education had significantly higher frequencies of satisfactory score in comparison to other groups 
$(55.2 \%)$. on the other hand, university graduated mothers showed significant higher frequencies of good score in comparison to the other two levels $(88.9 \%)$ and significant difference was found $(\mathrm{X} 2=$ 32.23, p-value $=0.000$ ).

Regarding the maternal occupation, working mothers had significantly higher frequencies of satisfactory score $(44.4 \%)$ or good score $(37.0 \%)$ in comparison to housewife mothers and significant difference was found $(\mathrm{X} 2=10.22$, $\mathrm{p}$-value $=0.006)$. It was noticed that the family size had no significant effect on the score of mother's knowledge ( $\mathrm{p}$-value $=0.074)$.

It was observed that positive family history for sickle cell anemia had no significant effect in the score of mother's knowledge ( $\mathrm{p}$-value $=0.711)$.

Table (7): Presents relationship between mothers' characteristics and their total level of reported practices.

Regarding the maternal educational level, university graduated mothers had significantly higher frequencies of satisfactory score $(77.8 \%)$ in comparison to the others two levels and significant difference was found $(\mathrm{X} 2=6.36$, $\mathrm{p}$-value $=0.041$ ).

Regarding the family size, mothers who had number of children from 1-3 in the family had significantly higher frequencies of satisfactory score $(64.3 \%)$ in comparison to mothers who had children more than three $(29.4 \%)$ score $(X 2=5.15, p$-value $=0.023)$.

It was noticed that neither mother's age, nor their occupation had significant effect on the score of mother's practices. Similarly, positive family history for sickle cell anemia was not associated with significant effect on the score of mother's practices $(\mathrm{p}$-value $=0.463)$.

Fig. (1): There is a statistical significant positive correlation between the level of mothers' knowledge and score of practices $(\mathrm{r}=0.451 \& \mathrm{P}=0.002)$.

\section{Discussion}

Based on the results of the present study, it was found that, the majority of mothers of children with sickle cell anemia were from urban areas while a minority of them were from rural areas (Table-1). This finding is in agreement with El-Beshlawy \& Youssry, (2009) who stated that in Egypt, along the Nile Valley, the HbS gene is almost nonexistent, but in the western desert near the Libyan border variable rates of 0.38 percent in the coastal areas to 9.0 percent in the New Valley oases have been reported. HbS carrier rates vary from 9 to 22 percent in some regions. This could be explained by the fact that New Valley governorate is a new one and most of the job chances in the capital of the governorate as well as the availability of other social, medical and economic services.
Results of the present study also showed that one third of the studied mothers were 40 years old or above (Table-1), this may lead to increased number of children with sickle cell anemia. This result is in agreement with Jeffrey et al., ( 2008) who stated that before pregnancy, partners should speak with their health care practitioner about their risk of having a baby with a genetic disorder. Risk factors include older age in the woman, a family history of genetic abnormalities, a previous baby with a birth defect, miscarriage, and a chromosomal abnormality in one of the prospective parents.

The current study showed that there was consanguineous marriage among the studied mothers (Table-1). Consanguineous marriage is still high in Egypt (35.3\%) especially among first cousins (86\%). However, the frequency varies by region. It is higher in Sohag (42.2\%) and Cairo (36.1\%) than in Assuit $(21.7 \%)$. Also it was higher in rural areas (59.9\%) than in semiurban and urban areas (23.5\%) and (17.7\%), respectively (Shawky et al., 2011).This favored the appearance of complex phenotypes of genetic disorders which result in difficulties in phenotype classification. Several genetic disorders have been reported to be frequent among Egyptians (Teebi, 2010, \& Afifi et al., 2010). This finding could be explained by the presence of traditional concept as most of mothers denying of the family history for fear of being accused of her child condition. In addition to the fact that most of mothers were from the urban areas.

Results of the present study showed that more than half of children with sickle cell anemia aged from 6 years to 12 years old (Table-2). This result is in agreement with William \& Shiel, (2013) who stated that Sickle cell anemia usually first presents symptoms in the first year of life and the affected infants do not develop symptoms in the first few months of life because the hemoglobin produced by the developing fetus (fetal hemoglobin) protects the red blood cells from sickling. This fetal hemoglobin is absent in the red blood cells that are produced after birth so that by 5 months of age, the sickling of the red blood cells is prominent and symptoms begin. This variation in age of presentation may be related to the absence of neonatal screening for abnormal hemoglobin, which will lead to delayment in detecting of such cases till school age.

Results of the present study also showed that more than half of children with sickle cell anemia were males while one third of them were females (Table2). In this context Maakaron, (2013) reported that the male-to-female ratio is $1: 1$. No sex predilection exists, since sickle cell anemia is not an X-linked disease. Although, no particular gender predilection has been shown in most series, analysis of the data 
from the ultra-sonography renal data system demonstrated marked male predominance of sickle cell nephropathy in affected patients.

Results of the present study showed that the most frequent clinical manifestations of sickle cell anemia were mild jaundice, change in urine color, fever, joints pain, severe abdominal pain and painful welling of hands and feet (Table-3). According to Woods, (2013) symptoms of sickle cell crisis include: pain, swelling in the hands and feet, fever, jaundice, pale skin color, chest pain, or episodic pain in joints, abdomen, or back, shortness of breath, fatigue, abdominal swelling, unusual or prolonged headache, any sudden weakness or loss of sensation, prolonged erection, and sudden vision changes. Acute manifestations most commonly include painful episodes and acute chest syndrome (Field \& DeBaun, 2009 \& Glassberg, 2011). Pain episodes are the leading cause of hospital admission for children with SCD, followed by acute chest syndrome, which in turn is the leading cause of death and admissions to the pediatric intensive care unit in children and ado lescents with SCD ( Powars \& Chan, 2005, Quinn \& Rogers, 2010). In a sample of over 100,000 SCD visits, the most common principal diagnosis for treat - and release visits as well as for hospitalization was SCD pain episode $(64.2 \%$ and 76.9\%, respectively) (Brousseau \& Owens, 2010).

Carrier detection, genetic counseling, premarital diagnosis, neonatal screening, preconception, prenatal diagnosis and selective screening programs are of great importance in the prevention of genetic disorders (Shawky et al., 2011). As regards the mothers' knowledge of SCA, the present study revealed that $60 \%$ of the mothers did not know the prevention of sickle cell anemia (Table -3).

In this study, it was found that infection is the most common precipitating factor of vaso-occlusive crisis, exposure to heat, and excessive physical exertion (table- 4). According to Maakaron, (2013) the precipitating factors of vaso-occlusive crisis include the following: hypoxemia: may be due to acute chest syndrome or respiratory complications, dehydration: acidosis results in a shift of the oxygen dissociation curve, changes in body temperature (eg, an increase due to fever or a decrease due to environmental temperature change. Also Beevi, (2009) stated that the common precipitating factors of sickle cell crisis include ;dehydration due to vomiting, diarrhea, increased sweating or exposure to heat, exposure to extreme climates, traveling to high altitude, excessive physical exertion, and infections.

Results of this study showed that mothers' knowledge about prevention of sickle cell crisis was early treatment during infection, avoid exposure to heat, early diagnosis and follow up (Table-4). This is in agreement with Woods, (2013) who stated that sickle cell anemia cannot be prevented. There are some general guidelines that may keep the condition under control: Take daily folic acid supplements, this will help to build new RBCs, Drink plenty of water to prevent dehydration, Avoid temperature extremes, Avoid overexertion and stress, Get plenty of rest, Get regular check-ups with knowledgeable healthcare providers, and Seek genetic counseling.

In the present study two thirds of mothers with sickle cell anemia were feeding their children a usual nutrition during crisis, half of them were avoiding the iron-rich food, while one quarter of them were increasing vegetables in food and two thirds of them were increasing fluid intake during sickle cell crisis (Table- 12). Good nutrition, while essential for anyone, is critical for patients with sickle cell disease. Some dietary recommendations include: Fluids are number one in importance. The patient should drink as much water as possible each day to prevent dehydration. Diet should provide adequate calories, protein, fats, vitamins and minerals. Patients and families should discuss vitamin and mineral supplements with their doctors and nurses. Some studies claim that omega-three fatty acids, found in fish and soybean oil as well as dietary supplements, might make red blood cell membranes less fragile and possibly less likely to sickle, although no studies have proven this definitively. Patients should take daily folic acid and vitamin B12 and B6 supplements. Vitamin B6 may have specific anti-sickling properties. Some studies recommend $1 \mathrm{mg}$ folic acid, 6 microgram vitamin B12, and $6 \mathrm{mg}$ vitamin B6. Foods containing one or all of these vitamins include meats, oily fish, poultry, whole grains, dried fortified cereals, soybeans, avocados, baked potatoes with skins, watermelon, plantains, bananas, peanuts, and brewer's yeast. However, folic acid can mask pernicious anemia, which is caused by deficiency of vitamin B12 and is more common in AfricanAmericans than other populations (Brown, 2011).

Results of the present study showed that there was a relation between level of knowledge and practice and mothers' educational level (Table-14\&15) where the educated mothers had significantly higher score of knowledge and practice about sickle cell anemia than those who didn't have education or had low educational standard. This finding is in the line with Bernsen et al., (2011) who found that knowledge score was lower in those women who didn't have education or have low educational standard. Nakhjavani et al., (2012) found that mothers with a university degree had actually better knowledge. 


\section{Conclusion}

Based on the resuls of the present study, it can be concluded that:

The low level of maternal education was a significant risk factor for the bad knowledge and poor practice of the mothers regarding management of sickle cell anemia. The majority of mothers who are working had a good knowledge about sickle cell anemia rather than those who were housewives. The smallest family size enhances the good practice during sickle cell crisis.

\section{Recommendations}

Based on the findings of the present study, the following recommendations are suggested:

- There is a dire need to arrange for health education program sessions for mothers about sickle cell anemia including causes, signs and symptoms, sickle cell crisis and management of sickle cell crisis.

- The importance of audio visual media which can be taken as means of communicating ideas and information about health, nutrition, complications, care of these cases and medicine to a mass audience.

- Effective genetic counselling, and concerted effort to identify families at increased risk, and to provide them with risk information and carrier testing when feasible.

- Planning and developing teaching and training programs for mothers. The education of mothers can be an important variable which affects their knowledge regarding disease and their practice of care for their children.

\section{References}

1. Afifi H., El-Ruby M., El-Bassyouni H., Ismail S., Aglan M., \& El-Harouni A., (2010): The most encountered groups of genetic disorders in Giza governorate. Egypt. 62-9. Quoted in Rabah M., *, Nermine S., Doaa S., \& Neveen S., (2012): The Egyptian Journal of Medical Human Genetics, Ain Shams University. Elsevier,vol 13, 45-62.

2. Ashley-Koch A., Yang Q., \& Olney R., (2000): Sickle hemoglobin $(\mathrm{HbS})$ allele and sickle cell disease: A HuGE review. American Journal of Epidemiology, 151(9), p: 839- 845. Quoted in Chow A., (2012): Asthma is associated with increased emergency department utilization for pain episodes in individuals with sickle cell disease, Master's Thesis in Biomedical Sciences, Mount Sinai School of Medicine.

3. Beevi A., (2009): Textbook of pediatric nursing. Nursing management of common hematological problems of children. $1^{\text {st }}$ edition., Elsevier, p:291-292.

4. Bernsen M., Al-Zahmi R., Al-Ali A., Hamoudi O., Ali A., Schneider J., Al-Mutawa J., \& Grivna M., (2011): Knowledge, Attitude and Practice towards Immunizations among Mothers in a Traditional City in the United Arab Emirates. Journal of Medical Sciences. P: 114-121.

5. Brousseau D., \& Owens C., (2010): "Acute care utilization and rehospitalizations for sickle cell disease." JAMA 303(13). P: 1288-1294.

6. Brown E., (2011): Sickle cell disease: Schools must do more, researchers say Bunn, H.F. (1997). Pathogenesis and treatment of sickle cell disease. N Engl J Med. 337. P: 762-769.

7. Dampier C., Ely B., Brodecki D., \& O'Neal P., (2002): Characteristics of pain managed at home in children and adolescents with sickle cell disease using diary self-reports. Journal of Pain, 3, 461-470. Quoted in Jones K., (2013): The relationship between executive functioning and adaptive functioning in pediatric sickle cell disease, Doctorate thesis in Philosophy, Drexel University.

8. El-Beshlawy A., \& Youssry I., (2009): Pediatric Hematology Department, Cairo University, Egypt, Vol. 33, No. s1, Pages S14-S20 Presented at 1st Pan-Middle Eastern Conference on Haemoglobinopathies, Damascus, Syria, 1-2 May 2009.

9. Field J., \& DeBaun M., (2009): "Asthma and sickle cell disease: two distinct diseases or part of the same process?" Hematology Am Soc Hematol Educ Program. p: 45-53.

10. Franck L., Treadwell M., Jacob E., \& Vichnisky E., (2002): Assessment of sickle cell pain in children and young adults using the Adolescent Pediatric Pain Tool. Journal of Pain and Symptom Management, 23. P:114-120. Quoted in Jones K., (2013): The relationship between executive functioning and adaptive functioning in pediatric sickle cell disease, Doctorate thesis in Philosophy, Drexel University.

11. Gil K., Porter L., Ready J., Workman E., Sedway J., \& Anthony K., (2000): Pain in children and adolescents with sickle cell disease: An analysis of daily pain diaries. Children's Health Care, 29. P: 225-241. Quoted in Bazen P., (2011): Cognitive Appraisal of Pain and „Other" Chronic Stressors in Adults Living with Sickle Cell Disease (SCD): Correlates and Predictors of Emotional and Quality of Life Outcomes, doctorate thesis in Philosophy, University of Rochester, Rochester, New York. 
12. Glassberg J., (2011): "Evidence-based management of sickle cell disease in the emergency department." Emerg Med Pract 13(8): 1-20; quiz 20.

13. http://web.b.ebscohost.com/ehost/detail/detail?vi $\mathrm{d}=13 \&$ sid $=5 \mathrm{a} 782650-5495-4 \mathrm{a} 5 \mathrm{e}-\mathrm{ad} 9 \mathrm{f}-$ 9ef9dea78d21\%40sessionmgr111\&hid=125\&

14. http://www.pubmedcentral.nih.gov/articlerender.f cgi?tool=pmcentrez\&artid=25664.

15. Jakubik L., \& Thompson M., (2000): Care of the child with sickle cell disease: acute complications, Pediatric Nursing, Vol. 26, Issue 4, 0097-9805. Quoted in Jakubik L., (2010): Nursing Care of the Child with Sickle Cell Disease:Acute Complications, Nursing of Children Network Conference.

16. Jeffrey S., Dungan M., \& Elias S., (2008): overview of genetic disorders.http://www.merckmanuals.com/home/ womens_health_issues/genetic_disorders_detecti on/overview_of_genetic_disorders.html overview of genetic disorders.

17. Kyla, R., \& Brendan P., (2009): Pain in Sickle Cell Disease (Sickle Cell Anemia), University of Michigan.

18. http://www.med.umich.edu/yourchild/topics/sick lecell.htm

19. Lemanek K., \& Ranalli M., (2009): Sickle cell disease. 4th ed In M.C. Roberts \& R.G. Steele (Eds). New York. Handbook of Pediatric Psychology. P: 303-318.

20. Maakaron E., (2013): MD d: Jan 28, 2013, Sickle Cell Anemia. http://emedicine.medscape.com/article/ 205926-overview\#a0156.

21. Nakhjavani Y., Soulmaz F., \& Nakhjavani F., (2012): Mothers' knowledge about fluoride therapy and fissure sealants.

22. Niscola P., Sorrentino F., Scaramucci L., Fabritiis P., \& Ciancuiulli P., (2009): Pain syndromes in sickle cell disease: An update. P: 470-480.

23. Platt O., Brambilia D., Rosee W., Milner P., Castro O., Steinberg, M., (1994): Mortality in sickle cell disease: Life expectancy and risk factors for early death. New England Journal of Medicine, 330. P:1639-1644. Quoted in Bazen P., (2011): Cognitive Appraisal of Pain and "Other " Chronic Stressors in Adults Living with Sickle Cell Disease (SCD): Correlates and Predictors of Emotional and Quality of Life Outcomes, doctorate thesis in Philosophy, University of Rochester, Rochester, New York.
24. Powars D., \& Chan L., (2005): "Outcome of sickle cell anemia: a 4-decade observational study of 1056 patients." Medicine (Baltimore) 84(6): 363-376. Quoted in Chow A., (2012): Asthma is associated with increased emergency department utilization for pain episodes in individuals with sickle cell disease, Master's Thesis in Biomedical Sciences, Mount Sinai School of Medicine.

25. Quinn C., \& Rogers Z., (2010): "Improved survival of children and adolescents with sickle cell disease." Blood 115(17): 3447-3452.

26. Shawky R., El-Awady M., Elsayed S., \& Hamadan G E ( 2011): Consanguineous matings among Egyptian population. Egypt J Med Hum Genet;12(2), doi:10.1016/j.ejmhg.07.001.

27. Smith J., \& Baker D., (2011): Sickle cell disease. In S. Goldstein \& C.R. Reynolds (Eds). Handbook of Neurodevelopmental and Genetic Disorders in Children ( $2^{\text {nd }}$ edition). New York: Guilford Press. P: 338-361.

28. Taylor L., Stotts N., Humphrey J., Treadwell M., \& Miakowski, C., (2010): A review of the literature on the multiple dimensions of chronic pain in adults with sickle cell disease. Journal of Pain \& Symptom Management, 40. P: 416-435.

29. Teebi A S (2010): Genetic disorders among Arab populations. Springer; p.68. Quoted in: Shawky R., Elsayed S., Ibrahim S., \& Seifeldin S., (2012): Profile of genetic disorders prevalent in northeast region of Cairo, Egypt. The Egyptian Journal of Medical Human Genetics 13, p: 4562.

30. Weatherall D., \& Clegg J., (2001): "Inherited haemoglobin disorder: an increasing global health problem". Bull. World Health Organ. 79 (8): 704-12. PMC 2566499. PMID 11545326. Quoted in Alshaiban A., (2013): Effect of heparin derivatives versus $\mathrm{P}$-selection inhibitor on the cellular adhesion: A potential approach in the management of sickle cell disease, Master's Thesis in Biotechnology Sciences, faculty of Albany, college of pharmacy and health sciences.

31. William C., Shiel J., (2013): Sickle Cell (cont.) http://www.nytimes.com/health/guides/disease/si ckle-cell-anemia/prevention-and-lifestylechanges.html.

32. Woods, M., (2013): sickle cell anemia, NYU Langone Medical Center | Department of Pediatrics | 462 First Avenue, New York, http://pediatrics.med.nyu.edu/conditions-wetreat/conditions/sickle-cell-anemia 